\title{
Lady Ada: Limor Fried, Adafruit Industries, Intellectual Property and Open Source Hardware
}

\author{
Matthew Rimmer*
}

\begin{abstract}
This paper provides a profile of Limor Fried of Adafruit Industries - as an advocate of open source hardware, and a policy campaigner for intellectual property law reform. This work considers the copyright challenges for open source hardware - particularly with the US Supreme Court decision on copyright subsistence in Star Athletica LLC. $v$ Varsity Brands Inc., and ongoing conflicts over intermediary liability and technological protection measures. It reviews the trademark disputes of Adafruit Industries - looking at the matter of Fried vinco Inc. It explores the intervention of the Open Source Hardware Association in the design patent dispute in Luxembourg $v$ Home Expressions Inc. It analyses how Adafruit Industries has engaged in defensive patenting, and pushed for patent law reform in dialogues with President Barack Obama. The conclusion considers how open source hardware advocates such as Limor Fried and Adafruit can play an important role in intellectual property law reform in the future. It also explores current and future challenges for Adafruit and open source hardware including the current coronavirus COVID-19 public health crisis.
\end{abstract}

\section{Keywords}

Open Source Hardware, Intellectual Property, Copyright Law, Technological Protection Measures, Designs Law, Trademark Law, Patent Law, Trade Secrets, 3D Printing, Open Licensing, Open Source Software, Free Software, Creative Commons, Coronavirus COVID19.

\section{Introduction}

Limor Fried is a US electrical engineer, and the owner of the company Adafruit Industries (Adafruit). She is also known by the nickname Lady Ada in reference to Ada Lovelace. ${ }^{1}$ Limor

\footnotetext{
Dr Matthew Rimmer (BA/LLB ANU, Phd UNSW) is a Professor in Intellectual Property and Innovation Law at the Faculty of Law in the Queensland University of Technology (QUT). Dr Rimmer is the chief investigator in the ARC Discovery Project, 'Inventing the Future: Intellectual Property and 3D Printing' (20172020) (DP 170100758).

$1 \quad$ W Isaacson, The Innovators: How a Group of Hackers, Geniuses and Geeks Created the Digital Revolution (Simon \& Schuster 2014) 7-34; J Essinger, Ada's Algorithm: How Lord Byron's Daughter Ada Lovelace Launched the Digital Age (Melville House 2014); C Hollings, U Martin and A Rice, Ada Lovelace: The Making of a Computer Scientist (University of Oxford 2018); CL Evans, Broad Band: The Untold Story of the
} 
Fried is a leading figure in the Open Source Hardware community. ${ }^{2}$ She participated in the first Open Source Hardware Summit and helped draft the Open Source Hardware Definition. Limor Fried studied at MIT. She obtained a Bachelor of Science in Electric Engineering and Computer Science in 2003 and a Master of Engineering in 2005. She wrote an anti-surveillance project called Social Defense Mechanisms: Tools for Reclaiming Our Personal Space. ${ }^{3}$ Limor Fried established Adafruit in 2005. The company focuses upon the design and sale of open source electronic kits, components, and tools. Adafruit has been profiled as one of the 'KitchenTable Industrialists' of local manufacturing. ${ }^{4}$ In an interview, Fried discusses the business model in respect of Adafruit: 'I like to say that Adafruit is a tutorial company, and an educational company, and we have a gift shop at the end'. 5 She added: 'I want to make a world where everyone is a maker, everyone's creative with electronics'. ${ }^{6}$ The work of Fried and Adafruit also taps into the larger Maker Movement. Chris Anderson - the author of Makers ${ }^{7}$ interviewed Limor Fried on the DIY revolution in $2011 .^{8}$

Rather than relying upon proprietary protection, Adafruit has espoused a philosophy of open source hardware. On its website, the company explains its credos: 'Open source hardware is hardware whose design is made publicly available so that anyone can study, modify, distribute, make and sell the design or hardware based on that design'. ${ }^{9}$ Adafruit explained its preference

Women who Made The Internet (Penguin 2018) 13-24; and Lizzie O'Shea, Future Histories: What Ada Lovelace, Tom Paine, and the Paris Commune Can Teach Us About Digital Technology (Verso Books 2019).

2 For an excellent overview of the open source hardware movement, see A Gibb (ed.), Building Open Source Hardware: DIY Manufacturing for Hackers and Makers (Addison-Wesley 2015). See also: J-P Ferdinand, Entrepreneurship in Innovation Communities: Insights from 3D Printing Startups and the Dilemma of Open Source Hardware (Springer 2017).

3 L Fried, Social Defense Mechanisms: Tools for Reclaiming our Personal Space, Thesis (M. Eng.), (MIT 2005).

4 A Girdharadas, 'The Kitchen-Table Industrialists', The New York Times, 13 May 2011, $<$ https://www.nytimes.com/2011/05/15/magazine/the-kitchen-table-industrialists.html>

5 TechCrunch, 'Adafruit's Limor Fried on Building a Hardware Company in the US', YouTube, 1 May 2013, <https://www.youtube.com/watch?v=9b_K2kmCTDI>

$6 \quad$ ibid

$7 \quad$ C Anderson, Makers: The New Industrial Revolution (Crown Business 2012)

$8 \quad$ C Anderson, 'Q\&A: Open Source Electronics Pioneer Limor Fried On the DIY Revolution', Wired, 29

March 2011, <https://www.wired.com/2011/03/ff_adafruit/>

$9 \quad$ Adafruit, $<$ https://www.adafruit.com/faq $>$ 
for open source hardware: 'Open source hardware gives people the freedom to control their technology while sharing knowledge and encouraging commerce through the open exchange of designs'. ${ }^{10}$ Adafruit commented: 'If any of our products include software or firmware to operate, we also provide all of the source code for your hacking pleasure. ${ }^{11}$ Adafruit has played a key role in the development of the Open Source Hardware Association (also described as the Association or OSHWA in this paper). The Association aims 'to foster technological knowledge and encourage research that is accessible, collaborative and respects user freedom.' ${ }^{12}$ The Association holds an annual Open Source Hardware Summit, maintains the Open Source Hardware certification, and undertake a range of community activities. ${ }^{13}$ Adafruit is part of a larger business sector, which relies upon open innovation. ${ }^{14}$ There has also been a number of commercial companies like IBM which have embrace open source software for pragmatic reasons. ${ }^{15}$

The company Adafruit has had to navigate through a number of tangled issues related to intellectual property (IP) - including copyright law, trade mark law, designs law, and patent law:

Adafruit is an open-source hardware company and promotes the values of open source through releasing hardware and software for others to build upon, share and improve. We use open source licenses which use copyright, and trademarks for our name and logos. A patent grants limited rights to inventors of a 'useful process, machine, article of manufacture, or composition of matter, or any new and useful improvement thereof'. For hardware this is incredibly complicated and 'patent trolls' abuse

\footnotetext{
$10 \quad$ ibid

11 ibid

12 Open Source Hardware Association, <https://www.oshwa.org/about/>

13 ibid

14 Y Benkler, 'The New Open-Source Economics', TedGlobal, 2005,

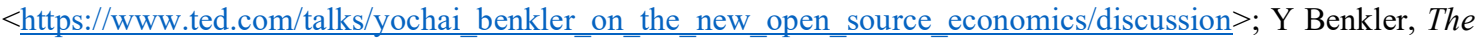
Wealth of Networks: How Social Production Transforms Markets and Freedom (Yale University Press, New Haven and London 2006); D Beldiman, 'From Bits to Atoms: Does the Open Source Software Model Translate to Open Source Hardware?' (2018) 35 Santa Clara High Technology Law Journal 23-53; and H Chesbrough, W Vanhaverbeke and J West (ed.), New Frontiers in Open Innovation, (Oxford University Oxford 2014).

15 P Samuelson, 'IBM's Pragmatic Embrace of Open Source' (2006) 49 (10) Communications of the ACM $21-25$.
} 
the patent system on a regular basis. There is much-needed reform of the patent and copyright system, instead of complaining about it, Adafruit will try to address some of the issues. ${ }^{16}$

Limor Fried and her company are advocates for IP law reform; and in the meantime, the company has sought to rely upon various practical strategies to manage, share, and defend IP. The advocacy of Limor Fried and Adafruit is an example of makers working for political and cultural change. ${ }^{17}$ Limor Fried has been celebrated and honoured in a variety of ways for her work in open source hardware - including a Pioneer Award by the Electronic Frontier Foundation (EFF). ${ }^{18}$ The citation explained the nature of the award: 'A pioneer in the field of open-source hardware and software hacking, Lady Ada helps the general public engineer and adapt consumer electronics to better suit their needs.' 19

This paper is part of a larger collection of work, looking at IP, 3D printing, and the Maker Movement. It also builds upon past work at open innovation - looking at open culture, ${ }^{20}$ Wikipedia, ${ }^{21}$ open agriculture, ${ }^{22}$ open biology ${ }^{23}$ open medicine, ${ }^{24}$ and open clean technology. ${ }^{25}$

16 Adafruit, 'Let's Help Fix the Patent System Together' < https://www.adafruit.com/patents $>$

17 J Sayers (ed.), Making Things and Drawing Boundaries: Experiments in the Digital Humanities (the University of Minnesota Press 2017); J Hunsinger and A Schrock (ed.) Making Our World: The Hacker and Maker Movements in Context (Peter Lang Publishing 2019); and E Garber, L Hochtritt and M Sharma (ed.), Makers, Crafters, Educators: Working for Cultural Change (Routledge 2019).

$18 \quad$ ibid

19 ibid

20 M Rimmer, 'Remix Culture and its Discontents', Chapter 8 of Digital Copyright and the Consumer Revolution: Hands off my iPod (Edward Elgar 2007).

21 M Rimmer, 'Wikipedia, Collective Authorship, and the Politics of Knowledge', in C Arup, and W van Caenegem (ed.), Intellectual Property Policy Reform: Fostering Innovation and Development (Edward Elgar 2009), 172-198.

22 M Rimmer, 'Japonica Rice: Intellectual Property, Scientific Publishing and Data-Sharing' (2005) 23 (3) Prometheus 325-347

23 M Rimmer, 'Beyond Blue Gene: Intellectual Property And Bioinformatics' (2003) 34 (1) International Review of Industrial Property And Copyright Law 31-49.

24 T Pogge, M Rimmer and K Rubenstein, (ed.) Incentives for Global Public Health: Patent Law and Access to Medicines (CUP, 2010).

25 M Rimmer, 'Elon Musk's Open Innovation: Tesla, Intellectual Property, and Climate Change', in M Rimmer (ed.), Intellectual Property and Clean Energy: The Paris Agreement and Climate Justice (Springer 2018), 515-551. 
In this respect, it follows in the methodological footsteps of Gabriella Coleman who has productively conducted anthropological studies of free software and the Anonymous movement. ${ }^{26}$ In this particular case, this paper engages in a biographical portrait of Limor Fried as part of an effort to better represent women in the history of information technology. ${ }^{27} \mathrm{It}$ follows in the tradition of Wirten's Making Marie Curie of telling life stories about intellectual property law, policy, and practice. ${ }^{28}$ This work uses the corporate case study of Adafruit to consider larger questions about IP, open source software, open source hardware, and the Maker Movement. Part 1 focuses upon a cluster of issues in respect of copyright law and open source hardware. Part 2 examines emerging conflicts in respect of trademark law and open source hardware. Part 3 investigates the impact of design patents in the US upon open source hardware. Part 4 explores the use of defensive patenting by open source hardware companies, and their advocacy for patent law reform. The conclusion considers larger challenges for Adafruit and the open source hardware movement - including the public health coronavirus COVID-19 outbreak in $2020 .^{29}$

\section{Copyright Law and Open Source Hardware}

In the field of computer software, there has been a reliance upon copyright law and related forms of protection - such as technological protection measures. The Free Software Foundation sought to resist proprietary models of protection through GNU Public Licence. ${ }^{30}$ The Open Source movement sought to share computer code through models of open licensing. ${ }^{31}$ The Creative Commons movement more generally has aimed to share copyright works through model licenses. ${ }^{32}$ Computer hardware has posed particular problems in respect of IP

26 G Coleman, Coding Freedom: the Ethics and Aesthetics of Hacking (Princeton University Press, 2012); and G Coleman, Hacker, Hoaxer, Whistleblower, Spy: The Many Faces of Anonymous (Verso 2014).

27 C L. Evans, Broad Band: The Untold Story of the Women who Made The Internet (n 1); and E Garber, L Hochtritt and M Sharma (ed.), Makers, Crafters, Educators: Working for Cultural Change (n 17).

28 EH Wirten, Making Marie: Intellectual Property and Celebrity Culture in an Age of Information (The University of Chicago Press 2015).

29 The City of New York, 'Mayor de Blasio Appoints Members to Sector Advisory Councils', Press Release, 6 May 2020, <https://www1.nyc.gov/office-of-the-mayor/news/326-20/mayor-de-blasio-appointsmembers-sector-advisory-councils $>$

30 R Stallman, Free Software, Free Society: Selected Essays (Free Software Foundation 2002).

31 G Moody, Rebel Code: Linux and the Open Source Revolution (Basic Books 2001).

32 P Stacey and SH Pearson, Made with Creative Commons (Crtl+Alt+Delete Books, 2017). 
classification. ${ }^{33}$ In this context, Open Source Hardware licensing provides a framework for licensing hardware designs. ${ }^{34}$ There are a number of different of Open Source Hardware licenses, and they have gone through a number of iterations and revisions. ${ }^{35}$ Eli Greenbaum has argued that an open source hardware license 'could be instrumental in creating a "commons" where the free exchange of design information can flourish. ${ }^{36}$ Nonetheless, there have been a number of tensions between copyright law, and open source hardware.

\section{A. Copyright Subsistence}

Copyright law has struggled to adapt and accommodate information technology into its schema. Beldiman has observed that Open Source Hardware raises issues in respect of copyright subsistence to the extent that they involve utilitarian products: 'Copyright protection for physical three-dimensional objects is generally limited to products which are artistic in nature. ${ }^{37}$ She comments: 'Absence of copyright protection for utilitarian OSH products means that an inventor cannot bind downstream licensees by a right that arises automatically., ${ }^{38}$

The Open Source Hardware Association was part of an amici curiae brief to the US Supreme Court in the case of Star Athletica LLC. v Varsity Brands Inc. on copyright protection in respect of fashion items. ${ }^{39}$ The submission explained that the Association is 'a non-profit organization

33 A Huang, The Hardware Hacker: Adventures in Making and Breaking Hardware (No Starch Press 2017), 175-179.

34 E Greenbaum, '3D Printing and Open Source Hardware' (2013) 2 New York University Journal of Intellectual Property and Entertainment Law 257-293; and D Beldiman, 'From Bits to Atoms: Does the Open Source Software Model Translate to Open Source Hardware?' (2018) 35 Santa Clara High Technology Law Journal 23-53.

35 Open Source Hardware Association, 'FAQ', <https://www.oshwa.org/faq/>

36 E Greenbaum, '3D Printing and Open Source Hardware' (n 34) at 287.

37 D Beldiman, 'From Bits to Atoms: Does the Open Source Software Model Translate to Open Source Hardware?' (n 34) at 53.

$38 \quad$ ibid

39 Brief of Public Knowledge, the International Costumers Guild, Shapeways, Inc., the Open Source Hardware Association, Formlabs Inc., Printrbot Inc., the Organization for Transformative Works, the American Library Association, the Association of Research Libraries, and the Association of College and Research Libraries as Amici Curiae in Support of Petitioner in Star Athletica LLC. v Varsity Brands Inc. 2016 WL 3965163 (U.S.) (Appellate Brief). 
designed to be the voice of the open source hardware community ${ }^{40}$ The submission stressed: 'A large percentage of open hardware source hardware combines both creative and functional elements'. ${ }^{41}$ In its view, 'Understanding the licensing requirements of open source hardware begins with understanding how copyright might apply. ${ }^{2} 2$

Other members of the brief included Public Knowledge, the International Costumers Guild, Shapeways, Inc., Formlabs Inc., Printrbot Inc., the Organization for Transformative Works, the American Library Association, the Association of Research Libraries, and the Association of College and Research Libraries.

In the submission, it was first argued that a 'high bar to conceptual separability serves fundamental interests of individuals and the public'. ${ }^{43}$ It was contended that 'creative consumers of all stripes depend on limited copyright in useful articles'. ${ }^{44}$ The submission observed that 'styles of clothing, at issue in this case, implicate basic rights of speech and association'. ${ }^{45}$

Second, the submission maintained that copyright limitations on useful articles promoted creativity and fair competition. The brief suggested that 'numerous industries thrive despite lack of substantial copyright protection - and likely because of it'. ${ }^{46}$ There has been some significant scholarly research undertaken on subject matter at the margins of copyright law. ${ }^{47}$ The submission also suggested that economic studies warned against expanding copyright protection into new fields, and further diminishing the public domain.

\footnotetext{
$40 \quad$ ibid

$41 \quad$ ibid

42 ibid

43 ibid

$44 \quad$ ibid

45 ibid

46 ibid

$47 \quad$ C Sprigman and K Raustiala, The Knockoff Economy: How Imitation Sparks Innovation (OUP 2012); K

Darling and A Perzanowski (ed.), Creativity without Law: Challenging the Assumptions of Intellectual Property (NYU Press 2017); and E Bonadio and N Lucchi (ed.), Non-Conventional Copyright: Do New and Atypical Works Deserve Protection? (Edward Elgar Publishing 2018).
} 
Third, the submission sought to try to keep the range of copyrightable subject matter within firm boundaries in order to preserve and conserve the intellectual commons - especially to avoid 'unnecessary barriers to access to useful articles. ${ }^{48}$ It argued that patent law was a more appropriate regime for the protection of useful articles

The majority of the US Supreme Court found in favour of copyright protection being granted in respect of the cheerleaders' costumes. ${ }^{49}$ Thomas $\mathrm{J}$ wrote the main opinion, emphasizing: 'We hold that an artistic feature of the design of a useful article is eligible for copyright protection if the feature (1) can be perceived as a two- or three-dimensional work of art separate from the useful article and (2) would qualify as a protectable pictorial, graphic, or sculptural work either on its own or in some other medium if imagined separately from the useful article. ${ }^{50}$ His Honour found that 'the designs on the surface of respondents' cheerleading uniforms in this case satisfy these requirements. ${ }^{51}$ Ginsburg $\mathrm{J}$ filed a concurrence.

Breyer $\mathrm{J}$ filed a dissenting opinion, in which Kennedy $\mathrm{J}$ joined. His Honour commented that 'the majority has lost sight of its own important limiting principle.' ${ }^{52}$ Breyer J stressed: 'One may not "claim a copyright in a useful article merely by creating a replica of that article in some other medium," such as in a picture. ${ }^{, 53}$

Given the nature of its work, Adafruit was anxious about the implications of the US Supreme Court decision. ${ }^{54}$ The Maker Movement and the 3D Printing community was worried about the ramifications of the ruling for the future operation of their community and industry. ${ }^{55}$ There

\footnotetext{
$48 \quad$ ibid

$49 \quad$ Star Athletica, LLC v Varsity Brands Inc. 137 S. Ct. 1002 (2017).

$50 \quad$ ibid at 1016.

$51 \quad$ ibid at 1016.

$52 \quad$ ibid at 1036 .

53 ibid at 1036.

54 Adafruit, 'The Supreme Court Ruled that Varsity Brands' Cheerleading Uniform Designs are Protected by Copyright Law', Blog, 24 March 2017, < https://blog.adafruit.com/2017/03/24/the-supreme-court-ruled-that-

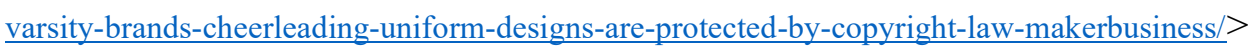

55 M Weinberg, 'Decision in the Cheerleader Uniform Case and a New Test for Copyright', Shapeways Blog, 22 March 2017, < $\underline{\text { https://www.shapeways.com/blog/archives/29985-decision-in-the-cheerleader-uniform- }}$ case-and-a-new-test-for-copyright.html>
} 
has been a number of applications of the US Supreme Court decision by lower courts - such as in a case, in which a banana costume was treated as a copyright work. ${ }^{56}$

\section{B. Intermediary Liability}

There has been some disquiet about how intermediary liability will affect online service providers, such as Adafruit. In its Terms of Service, Adafruit stresses: 'It is your responsibility to make sure that your activities comply with applicable laws, including copyright. ${ }^{57}$ Adafruit has sent a takedown notice to Google in respect of the website, 5 fruitindustries.blogspot.com. ${ }^{58}$ The US Copyright Office has been threatening to expand intermediary liability under copyright law. Samuelson has argued that the Office has failed to consider the position of intermediaries similar to Adafruit: 'What about, for instance, the usercreators who depend on OSPs such as Etsy or Ravelry to make their creations available? ${ }^{59}$ There is a need to ensure that intermediary liability regime does not impose undue burdens upon online service providers.

\section{Technological Protection Measures}

As Yochai Benkler observes, the efforts of copyright industries to impose digital locks upon copyright works has been resisted by the information technology sector. ${ }^{60} \mathrm{He}$ commented that the computer hardware and software industries have been concerned that such laws would undermine their innovation and creativity.

\footnotetext{
$56 \quad$ Silvertop Associates., Inc. v Kangaroo Manufacturing., Inc. 319 F. Supp. 3d 754 (D.N.J. 2018).

57 Adafruit, 'Terms of Service' $<$ https://www.adafruit.com/terms_of_service/>

58 Adafruit, 'Re: Infringement $\quad$ Notification $\quad$ Bia <https://www.lumendatabase.org/notices/1949487\#>

59 P Samuelson, 'The US Copyright Office Section 512 Study: Why the Entertainment Industry Is Claiming Victory', Kluwer Copyright Blog, 25 May 2020, <http://copyrightblog.kluweriplaw.com/2020/05/25/the-uscopyright-office-section-512-study-why-the-entertainment-industry-is-claiming-victory/>

60 Y Benkler, The Wealth of Networks: How Social Production Transforms Markets and Freedom (n 14) 25 .
} 
Microsoft has traditionally taken a proprietarian approach to the copyright protection of computer software. For many years, Bill Gates was hostile to open source models of production - until a late mellowing when his work turned to philanthropic endeavours. ${ }^{61}$

In 2010, Microsoft launched Kinect, an accessory which enabled players to control Xbox 360 games by moving their bodies. ${ }^{62}$ In response, Fried posted a challenge on her company's blog, Adafruit, to provide a prize of $\$ 3,000$ to the first person who would be able to unlock Kinect's motion sensors. ${ }^{63}$ There was much media interest in the reverse engineering of Kinect. ${ }^{64}$

Microsoft was unhappy about the challenge at the time, declaring that the company 'did not condone the modification of its products' or 'product tampering'. ${ }^{65}$ The company emphasized that 'Microsoft will continue to make advances in these types of safeguards and work closely with law enforcement and product safety groups to keep Kinect tamper-resistant' ${ }^{66}$ Subsequently, Microsoft relented, and said that no one would get in trouble through making open source drivers. ${ }^{67}$ There has been perhaps a mellowing of Microsoft's approach to open source software under CEO Satya Nadella. ${ }^{68}$

There has been a challenge to the constitutional validity of technological protection measures (TPMs) under the Digital Millennium Copyright Act 1998 (US) (DMCA) by Matthew Green,

61 C Metz, 'Meet Bill Gates, The Man Who Changed Open Source Software', Wired Magazine, 30 January 2012, < https://www.wired.com/2012/01/meet-bill-gates/>

62 Bloomberg Business, 'Adafruit Targets Tinkerers With “Open-Source” Electronics Kits', Bloomberg Business, 7 December 2010, <https:/www.bloomberg.com/news/articles/2010-12-06/adafruit-targets-tinkererswith-open-source-electronics-kits>

63 Adafruit, 'The Open Kinect Project - The OK Prize - Get \$3,000 Bounty for Kinect for Xbox 360 Open Source Drivers', Blog, 4 November 2010, < https://blog.adafruit.com/2010/11/04/the-open-kinect-project-the-okprize-get-1000-bounty-for-kinect-for-xbox-360-open-source-drivers/>

$64 \quad$ J Giles, 'Inside the Race to Hack the Kinect' (2010) 208 (2789) New Scientist 22-23.

65 D Terdiman, 'Bounty Offered for Open-Source Kinect Driver', CNet, 4 November 2010, $<$ https://www.cnet.com/news/bounty-offered-for-open-source-kinect-driver/>

$66 \quad$ ibid

67 NPR, 'How The X-Box Kinect Tracks Your Moves', NPR, 19 November 2010, <https://www.npr.org/2010/11/19/131447076/how-the-X-box-kinect-tracks-your-moves>

68 M Radits. A Business Ecology Perspective on Community-Driven Open Source: The Case of the Free and Open Source Content Management System Joomla (Linköping University Electronic Press 2019). 
Andrew 'Bunnie' Huang, and Alphamax LLC. ${ }^{69}$ In 2019, Sullivan J of the US District Court for the District of Columbia handed down a mixed decision in the dispute. ${ }^{70}$ The judge allowed the 'as applied' First Amendment claims could go forward because 'the DMCA's prohibition on circumvention and trafficking appears to burden the accessing, sharing, publishing, and receiving of information'. ${ }^{71}$ However, Sullivan J rejected the arguments that rulemaking by Librarian of Congress was subject to judicial review under the Administrative Procedure Act, or First Amendment scrutiny. Sullivan J also saw no need to adjudicate the claims that section 1201 of the $D M C A$ was overbroad.

Huang explained his activism in this field in his manifesto, The Hardware Hacker ${ }^{72}$ He feared: 'If we allow technology to become a black box, we also surrender our agency to the companies and governments that produce and regulate it. ${ }^{, 73}$ Fried is very much a kindred spirit to Huang,

\section{Trademark Law and Open Source Hardware}

There has been some debate about the role of trademark law in the open source community. Bowrey has written about Linux as a registered trademark of Linus Torvalds. ${ }^{74}$ She has discussed how trade mark law has been the source of tensions within the open source community. Likewise, there has been a discussion about the application of trademark law in

\footnotetext{
69 Complaint for Declaratory and Injunctive Relief in Green, Huang and Alphamax LLC v Lynch, Hayden, and Pallante (2016) https://www.eff.org/document/1201-complaint and https://www.eff.org/files/2016/07/21/1201 complaint.pdf See also A Huang, The Hardware Hacker: Adventures in Making and Breaking Hardware (n 33).

$70 \quad$ Green v U.S. Department of Justice 2019 WL 2647992 (US District Court for the District of Columbia). 71 ibid.

72 A Huang, The Hardware Hacker: Adventures in Making and Breaking Hardware (n 33), 178.

73 ibid, 179.

74 K Bowrey, Law and Internet Cultures (CUP 2005), 81-100.
} 
respect of 3D Printing. ${ }^{75}$ There has also been a spectrum of views about the suitability of trade marks in the Fab Lab community. ${ }^{76}$

In this context, it is notable that Adafruit has sought to register trademarks; as well as defend itself against allegations of trademark infringement. Adafruit had developed a portfolio of trade marks. ${ }^{77}$ The trade marks include 'Adafruit', 'Adafruit Perma-Proto', the 'Adafruit Star Design Mark', 'Adabox', 'Adalogger', 'Ask an Engineer', the 'Linka Logo' in colour and black and white, 'Bluefruit', 'Braincraft', 'Circuit Playground', 'Circuitpy', 'CircuitPython', 'Citizen Engineer', 'Cobbler, 'Dronies \& Design', 'Dragontail', 'feather', 'feather wing', Flora \& Design', 'Fona', 'Gemma', 'Glider', 'Huazzah', 'Ice Tube', 'Make Outside the Box', 'Menta', 'Metro', 'Minerva, 'Mintyboost', 'Monochron', 'Neopixel', 'Pyportal', 'Radiofruit', 'Seesaw', 'Stemma', 'Think Ink', 'TinyUSB \& Design', 'Trash Panda' and logo, 'T-Cobbler', 'Trellis', 'Trinket', 'Veter', and 'Xoxbox'. There are even trademarks registered for 'LadyAda' for the use in circuit-boards and storybooks by Adafruit.

Adafruit have been inspired by trademark guidelines for open source projects. ${ }^{78}$ The model guidelines drafted by Pamela Chestek are 'designed to provide a range of choices that would be found lawful and enforceable under trademark law, that are consistent with FLOSS culture, and that respect the trademark owner's desire to ensure that the software distributed under the trademark delivers a consistent user experience and meets the brand promise of the name. ${ }^{, 79}$

On January 24, 2012, Adafruit filed a trademark application with the US Patent and Trademark Office (USPTO) for its mark FLORA for 'open-source wearable electronic boards' and other

75 A Scardamaglia, 'Trade Mark Controversies in 3D Printing: An Australian Perspective', in D Mendis, M Lemley, and M Rimmer (ed.), 3D Printing and Beyond: Intellectual Property and Regulation (Edward Elgar Publishing 2019), 308-324; and D Hong and S Bradshaw, 'Digital Trade Mark Infringement and 3D Printing Implications: What Does the Future Hold?' in D Mendis, M Lemley, and M Rimmer (ed.), 3D Printing and Beyond: Intellectual Property and Regulation (Edward Elgar Publishing 2019), 99-114.

$76 \quad$ M Menichinelli (ed.) Fab Lab: Revolution Field Manual (Niggli 2017), 31.

77 Adafruit, 'Trademarks', < $\underline{\text { https://www.adafruit.com/trademarks }>}$

78 Adafruit, 'Trademark Guidelines for open source projects and more... \#makerbusiness', Blog, 10 February 2014, <https://blog.adafruit.com/2014/02/10/trademark-guidelines-for-open-source-projects-and-moremakerbusiness/>

79 ibid 
computer products in Class 9 and 'jewelry; bracelets; pendants; cufflinks; watches; pins being jewelry; lapel pins; broaches' in Class $14 .{ }^{80}$

In the 2013 case of Fried $v$ Linco Inc., Adafruit asked the US District Court for the State District of New York Court for a declaratory judgment in a trade mark dispute with a Californian company, Linco Inc.. ${ }^{81}$ The lawsuit noted that 'Adafruit is a one of kind, quirky and some may say 'geeky' electronics company whose FLORA products are used, for example, to sew lights into jackets that illuminate when a specified location is reached and/or neckties that respond to the cadence of one's own voice.' ${ }^{82}$ By contrast, the lawsuit noted that the Defendant 'sells photography lighting equipment such as florescent light banks to professional photographers under the mark FLORA'. ${ }^{83}$ The complaint observed: 'Although Adafruit and Defendant clearly sell different goods to different types of customers, Defendant has threatened to sue to prevent Adafruit's continued use of its mark. ${ }^{84}$ The lawsuit lamented: 'It is inconceivable that consumers will confuse Plaintiffs and Defendant's specialized products' ${ }^{85}$ Adafruit asked the court to enter: (1) a declaratory judgment that Adafruit's use of the mark FLORA and Design does not constitute trademark infringement or unfair competition and (2) to enter an Order directing the Director of the U.S. Patent and Trademark Office to cancel Defendant's registration No. 4,022,545 for the mark FLORA on the grounds of fraud

The complaint outlines the nature of the business of Adafruit: 'Founded in 2005, Adafruit sells do-it-yourself kits to create various electronic products, such as clocks, cell phone chargers, toys and light-up jewellery.' ${ }^{86}$ The submission notes that 'Adafruit's projects are open source, meaning that the designs and programming instructions are made available for customers to construct everything themselves'. ${ }^{87}$ The company outlines that its community is based in the Maker Movement - 'Adafruit's customers are the community of "makers," hackers, crafters, artists. designers and engineers'; 'Adafruit's sells its products on its website, and via other

$\begin{array}{ll}80 & \text { Adafruit, 'Flora', U.S. Trademark Registration No. } 85524107 \\ 81 & \text { Fried v Linco Inc. } 2013 \text { WL } 2400891 \text { (S.D.N.Y.) (Trial Pleading) } \\ 82 & \text { ibid. } \\ 83 & \text { ibid. } \\ 84 & \text { ibid. } \\ 85 & \text { ibid. } \\ 86 & \text { ibid. } \\ 87 & \text { ibid. }\end{array}$


online "do-it-yourself" retailers'; and 'Adafruit's business is unique and cutting edge in the "DIY" world.' 88 Accordingly, 'Adafruit's consumers are sophisticated and highly skilled electronics enthusiasts.' ${ }^{89}$

Linco filed an application for the word mark FLORA on the 10 February 2011 for a range of goods related to lighting. Adafruit received a letter from the defendant's lawyers in 2013, alleging that Adafruit "infringed on [Defendant's] said U.S. trademark 'FLORA AND DESIGN' by illegally using the 'FLORA AND DESIGN' trademark on your LED products and selling these infringing products on the websites...". ${ }^{90}$ In the letter, Defendant threatened that 'selling the infringing products is illegal and punishable by civil and criminal courts according to the trademark and IP laws and regulations. ${ }^{91}$

In response, Adafruit first sought a declaration of non-infringement of the trademark: 'The parties' respective goods are non-competing, sold in different channels of trader, promoted and sold to different customs and targeted to different customers'. ${ }^{92}$ Adafruit maintained: 'There is no likelihood of confusion, mistake, or deception among consumers as to whether Plaintiff and/or its products are associated with, sponsored by, connected to, or affiliated with Defendant because of, among other reasons, the differences in goods, channels of trade and intended customers. ${ }^{93}$ Accordingly, Adafruit insisted: 'Adafruit's use of the mark FLORA and Design on its wearable electronic platform does not infringe upon the trademark rights held by Defendant in the mark FLORA.' 94

Second, Adafruit sought the cancellation of Linc's U.S. Trademark Registration No. 4,022,545 for 'Electric Warning Light Systems'. Adafruit contended that the 'Defendant's application and resulting registration contain false and fraudulent statements that the mark FLORA was in use in connection with "radio receivers and transmitters for monitoring and controlling light emitting diodes in a network of street lights and for processing emergency signals transmitted

\begin{tabular}{ll}
\hline 88 & ibid. \\
89 & ibid. \\
90 & ibid. \\
91 & Fried v Linco Inc. 2013 WL 2400891 (S.D.N.Y.) (Trial Pleading) \\
92 & ibid. \\
93 & ibid. \\
94 & ibid.
\end{tabular}


to individual street lights" among other goods'. ${ }^{95}$ Adafruit contended: 'Upon information and belief, as of August 29, 2012, when Adafruit filed the petition for cancellation, Defendant had never used the mark FLORA in connection with any LED products.' ${ }^{96}$ Adafruit alleged: 'Upon information and belief, Defendant only added LEDs to its line of products after receiving Plaintiffs petition for cancellation, which alleged that Defendant's mark was not in use in connection with LED lights. ${ }^{97}$ Adafruit contended: 'Plaintiff will be damaged by Registration No. 4,022,545 because Defendant has asserted the registration against Plaintiff in the marketplace in connection with goods that purport to compete with Plaintiff's goods and Plaintiff's use of the mark FLORA.' 98

In response, Linco. Inc. sought to dismiss the action. ${ }^{99}$ In its counterclaim, Linco Inc. argued that the 'Defendant has used Linco's identical Registered Trademark in connection with products in the same class as Linco's.' ${ }^{100}$ As part of its Counterclaim, Linco Inc. maintained that the 'Defendant's usage of Linco's Registered Trademark is likely to cause confusion among relevant consumers.' ${ }^{101}$ Linco maintained that the 'Defendant has violated the terms of the Lanham Act, codified at 15 U.S.C. 1051, et seq.' and 'Linco has suffered economic losses due to the trademark infringement, in violation of 15 U.S.C. 1051, et seq. ${ }^{102}$

In the end, according to the Trademark Trial and Appeal Board documents, there seemed to be a settlement between the parties. ${ }^{103}$ There was a withdrawal of the petition for cancellation of the trademark of Linco Inc. in respect of FLORA.

\footnotetext{
$95 \quad$ ibid.

$96 \quad$ Fried v Linco Inc. 2013 WL 2400891 (S.D.N.Y.) (Trial Pleading)

97 ibid.

98 ibid.

Fried v Linco Inc. 2013 WL 6778712 (S.D.N.Y.) (Defendant's Answer and Counterclaims)

100 ibid.

101 ibid.

102 ibid.

103 US Trademark Trial and Appeal Board Inquiry System, $<\underline{\text { http://tabvue.uspto.gov/ttabvue/v?pno=92056104> }}$
} 
Adafruit has taken notice of US Supreme Court rulings on offensive trade marks. ${ }^{104}$

The Open Source Hardware Association has had encountered its own problems and challenges in respect of its trade mark. In her history of the open source movement, Catarina Mota documents the conflict over trade marks in the open source field. ${ }^{105}$ She recounts that there was a need to mediate and resolve conflicts within the community between the Open Source Initiative and the Association over trade marks. ${ }^{106}$ The Association had to redesign its logo to avoid confusion with another trade mark.

Such disputes are perhaps an indication of how trademark register has become very cluttered. Beebe and Fromer have considered the growing problem of trademark depletion and congestion. ${ }^{107}$ The scholars commented that 'the American trademark system has always assumed the existence of an open frontier of unclaimed, competitively effective trademarks' ${ }^{108}$ As a result of their empirical research, the scholars conclude that 'the ecology of the trademark system is undergoing increasing strain'. ${ }^{109}$ They suggested that there needs to be a new approach to the stewardship of the trademark register. ${ }^{110}$

\section{Design Patents and Open Source Hardware}

\footnotetext{
104 Adafruit, 'Supreme Court - Government May Not Refuse to Register Potentially Offensive Names', Blog, 20 July 2017, <https://blog.adafruit.com/2017/06/20/supreme-court-government-may-not-refuse-to-

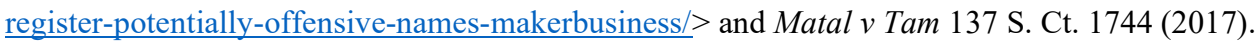

105 C Mota, 'History of the Open Movement' in A Gibb (ed.), Building Open Source Hardware: DIY Manufacturing for Hackers and Makers (Addison-Wesley 2015), 3-12.

106 ibid, 10.

107 B Beebe and J Fromer, 'Are We Running Out of Trademarks? An Empirical Study of Trademark Depletion and Congestion' (2018) 131 Harvard Law Review 945-1045.

108 ibid, 1042.

109 ibid, 1042.

110 ibid, 1042.
} 
There has been controversy over the evolution of design patents in the US. ${ }^{111}$ Burstein has written extensively about some of the policy problems in respect of design patents. ${ }^{112}$

There has been concern about the impact of design patents in the US upon 3D printing and additive manufacturing. ${ }^{113}$ Ferrill and her colleagues contend: 'In the age of 3D printing, design patents may be helpful in protecting innovative designs, particularly in preventing unauthorized printing of replacement parts'. ${ }^{114}$ However, there has been concern about the over-protection of design patents disrupting the open design community.

The Open Source Hardware Association made an amicus curiae submission in a dispute over design patents. ${ }^{115}$ The case involved Curver Luxembourg Inc. applying for a design patent on a wicker pattern for furniture. Amongst other things, the submission mentioned the innovative works of Adafruit. The Association sought to protect the interests of its community: 'Opensource hardware designers make their project design files publicly available so that anyone can study, modify, or make the designs or hardware based on them'. ${ }^{116}$ The Association sought 'to ensure that technological knowledge is accessible to everyone, and to encourage the collaborative development of technology that serves education, environmental sustainability, and human welfare.' 117

111 E Lee, M McKenna and D Schwartz, The Law of Design: Design Patent, Trademark, and CopyrightProblems, Cases, and Materials (West Academic Publishing 2017).

112 S Burstein, 'Moving Beyond the Standard Criticisms of Design Patents' (2013) 17 Stanford Technology Law Review 305; Sarah Burstein, 'The Patented Design’ (2015) 83 Tennessee Law Review 161-230; S Burstein, 'Costly Designs' (2016) 77 Ohio State Law Journal 107-157; S Burstein, 'The “Article of Manufacture” in 1887' (2017) 32 Berkeley Technology Law Journal 1-85; S Burstein, 'Is Design Patent Examination Too Lax?’ (2018) 33 Berkeley Technology Law Journal 607-626; and S Burstein, 'The “Article of Manufacture” Today’ (2018) 31 (2) Harvard Journal of Law and Technology 781-839.

113 E Ferrill, R MacKichan, C McKinley and K Horn, 'Integrating a Classic Tool for a Modern Challenge: US Design Patents Implications for 3D Printing', in D Mendis, M Lemley, and M Rimmer (ed.), 3D Printing and Beyond: Intellectual Property and Regulation (Edward Elgar Publishing, 2019), 185-202.

114 ibid, 185.

115 Brief on Behalf of Amicus Curiae Open Source Hardware Association in Support of Defendant-Appellee and Affirmance in Curver Luxembourg Inc. v Home Expressions Inc. 2018 WL 6975051

116 ibid

117 ibid 
The Association insisted that its 'only interest in this case is to preserve a balanced, clear scope of design patent protection'. ${ }^{118}$ The Association commented: 'A large percentage of opensource hardware combines both ornamental and functional elements, and industrial design routinely involves applying design concepts from disparate fields in novel ways.' 119 The Association maintained: 'To engage in this practice, open-source hardware designers need to know the universe of available source material and its limits. ${ }^{120}$ The Association maintained: 'To engage in its collaborative model of innovation, this diverse community depends on a clear and balanced scope of design patent protection.' ${ }^{121}$

In its argument, the Association first contended that 'the open-source hardware community is highly innovative and relies on clearly delineated design patent boundaries'. ${ }^{122}$ The Association provides examples of the diverse array of open projects - including the Open Hand Project (3D-printed robotic prosthetics), ${ }^{123}$ OpenROV (a submersible drone), ${ }^{124}$ and Open Motors (street electric vehicles). ${ }^{125}$ The Association discussed the work of Adafruit and SparkFun: 'Successful do-it-yourself e-commerce sites like SparkFun and AdaFruit provide the components necessary to incorporate Arduino's boards into new and inventive hardware designs'. ${ }^{126}$ The Association said that Adafruit developed open source wearable fashion. The Association insisted: 'To ensure that open-source hardware can maintain a similar manner and pace of innovation as this Court commended when discussing open-source software in Jacobsen, design patent protection must balance the interests of these important innovative contributors with those of design patent holders.' ${ }^{127}$

\footnotetext{
$118 \quad$ ibid

$119 \quad$ ibid

$120 \quad$ ibid

$121 \quad$ ibid

122 ibid

123 Open Hand Project, $<\underline{\text { http://www.openhandproject.org/ }><\text { http://www.openhandproject.org/dextrus.php }}$

124 OpenROV, < $\quad$ http://staging.openrov.com/ $>$ and $<\underline{\text { https: } / / \text { www.sofarocean.com } />}$

125 Open Motors, $<$ https://www.openmotors.co/>

126 Brief on Behalf of Amicus Curiae Open Source Hardware Association in Support of Defendant-Appellee and Affirmance in Luxembourg v Home Expressions Inc. 2018 WL 6975051

127 ibid
} 
Second, the Association argued that the 'Design patents protect the application of a design to an article of manufacture, in line with design practice and law'. ${ }^{128}$ The Association observed that 'the novel application of existing designs to new articles is itself valuable innovation.' 129 The Association contended that 'untethering the patented design from the article of manufacture would unnecessarily protect abstract designs at the expense of innovative design practice.' 130 The Association elaborated upon its argument: 'Extending design patent protection to abstract designs would foreclose a ubiquitous, useful, and creative method of design: applying existing designs to articles of manufacture in new and nonobvious ways'. ${ }^{131}$ The Association feared: 'The existing diversity of innovative designs from which the opensource hardware community may draw would diminish substantially if the scope of protection for patented designs lost its connection to the article of manufacture'. ${ }^{132}$

Third, the Association argued that 'reading the article of manufacture out of design patent protection would undermine design patent law's notice function and would chill innovation.' ${ }^{133}$ In its view, 'Patented designs must be tethered to their designated articles of manufacture in order for design patents to provide adequate notice of what they cover.' ${ }^{134}$ The Association maintained that 'Preserving notice of a design patent's scope is essential to limiting uncertainty and promoting efficient investment in innovation." ${ }^{135}$ The Association argued: 'The opensource model's public benefit would diminish considerably if fear of liability discouraged certification and sharing'. ${ }^{136}$ The Association argued: 'A design patent untethered to its article of manufacture would give inadequate notice as to what the patentee has contributed and owns, and as to what others are free to use, to improve, and to distribute to the public under an open

\begin{tabular}{ll}
\hline 128 & ibid \\
129 & ibid \\
130 & ibid \\
131 & ibid \\
132 & ibid \\
133 & ibid \\
134 & ibid \\
135 & ibid \\
136 & ibid
\end{tabular}


license'. ${ }^{137}$ The Association concluded that 'it is important to preserve the existing connection between a protected design and its designated article of manufacture. ${ }^{138}$

There was oral argument in the matter of Curver Luxembourg Inc. v Home Expressions Inc. in May 2019 before the US Court of Appeals for the Federal Circuit. ${ }^{139}$ The decision was handed down in September 2019. ${ }^{140}$ Chen J held: 'The question on appeal is whether the district court correctly construed the scope of the design patent as limited to the illustrated pattern applied to a chair, or whether the design patent covers any article, chair or not, with the surface ornamentation applied to it. ${ }^{141}$ Chen J observed: 'Because we agree with the district court that the claim language "ornamental design for a pattern for a chair" limits the scope of the claimed design in this case, we affirm. ${ }^{\text {, }}{ }^{2}$ Chen J concluded: 'Accordingly, we affirm the district court's grant of Home Expressions' motion to dismiss the complaint for failure to state a plausible claim of design patent infringement.' 143

In the public health crisis of the coronavirus COVID-19, Adafruit has had to pivot to develop medical devices and personal protective equipment. In this context, there has been some significant policy debate over the right to repair in respect of designs and other forms of IP. In this context, open source hardware is a useful means of alleviating concerns about the risks of IP infringement. ${ }^{144}$ The Open COVID Pledge has also been used by IP owners to flag that they would not take infringement action in respect of activity related to the coronavirus. ${ }^{145}$

At a more fundamental level, there is a disjuncture between industrial design laws and modern technologies such as information technology and $3 \mathrm{D}$ printing. This has not only been a problem

\footnotetext{
$137 \quad$ ibid

$138 \quad$ ibid

139 Curver Luxembourg Inc. v Home Expressions Inc. 938 F.3d 1334 (Fed. Cir. 2019)

$140 \quad$ ibid

$141 \quad$ ibid

$142 \quad$ ibid

143 ibid

144 J Pearce, 'Distributed Manufacturing of Open-Source Medical Hardware for Pandemics', (2020) 4 (2) Journal of Manufacturing and Materials Processing 49.

145

Open COVID Pledge $<\underline{\text { https://opencovidpledge.org/> }}$
} 
in the US, ${ }^{146}$ but it has also bedevilled design laws in Australia, ${ }^{147}$ the UK, ${ }^{148}$ and the EU. ${ }^{149}$ There may well need be more systematic reform and modernisation of designs law at both a national and an international level. There is also a burgeoning open design movement, seeking to make designs accessible and available. ${ }^{150}$

\section{Patent Law and Open Source Hardware}

There has been a long-running fierce debate about the impact of the patents upon computer software and computer hardware. ${ }^{151}$

The Free Software Foundation has been active in disputes over the boundaries of patentable subject matter. For instance, in the Bilski v Kappos dispute, the Free Software Foundation argued in an amicus brief that 'software patents hinder the progress of software development and distribution'. 152

Likewise, the Software Freedom Law Center, Free Software Foundation, and Open Source Initiative made a submission in Alice v CLS Bank International, warning against 'statutory

146 E Ferrill, R MacKichan, C McKinley and K Horn, 'Integrating a Classic Tool for a Modern Challenge: US Design Patents Implications for 3D Printing’ (n 113).

147 M Adams, "The "Third Industrial Revolution": 3D Printing Technology and Australian Designs Law" (2015) 24 (1) Journal of Law, Information and Science; and T Berger, "'Substantial Similarity” Under Australian Law: Application to 3D Printing', in D Mendis, M Lemley, and M Rimmer (ed.), 3D Printing and Beyond: Intellectual Property and Regulation (Edward Elgar Publishing, 2019), 294-307.

148 T Margoni, 'Design Rights and 3D Printing in the UK: Balancing Innovation and Creativity in a (Dis)harmonised and Fragmented Legal Framework', in D Mendis, M Lemley, and M Rimmer (ed.), 3D Printing and Beyond: Intellectual Property and Regulation (Edward Elgar Publishing, 2019), 77-98.

149 M Norrgard, RM Ballardini and MM Kasi, 'Intellectual Property Rights in the Era of 3D Printing', in RM Ballardini, M Norrgard and J Partanen (ed.), 3D Printing, Intellectual Property and Innovation: Insights from Law and Technology (Kluwer Law International, 2017), 63-78.

150 L Cruickshank, Open Design and Innovation: Facilitating Creativity in Everyone, Farnham (Surrey): Gower Publishing, 2014.

$151 \quad$ Y Benkler, The Wealth of Networks: How Social Production Transforms Markets and Freedom (n 14) 312.

152 Brief of Free Software Foundation as Amicus Curiae in Support of Respondent in Bilski v Kappos 2009 WL 3199627. 
monopolies for computer-implemented inventions. ${ }^{153}$ While the US Supreme Court has not accepted blanket calls for banning software patents, the US Supreme Court has taken a stricter approach in setting the boundaries of patentable subject matter. ${ }^{154}$

Pearce has emphasized that 'patent law is the primary concern' for Open Source Hardware. ${ }^{155}$ He has stressed that scientists and engineers will have to navigate their way through patent thickets - which in his view are 'an intellectual minefield'. ${ }^{156}$ Pearce concludes that 'there is still a great need for bolstering the legal position of the public domain and creative defensive publications to protect the intellectual commons from the last of the poachers.' ${ }^{157}$

There has been a larger debate as to whether the patent system will be able to accommodate $3 \mathrm{D}$ printing and related technologies. Lemley has maintained that $3 \mathrm{D}$ printing will disrupt patent law, because it will challenge its underlying economics of artificial scarcity. ${ }^{158}$ By contrast, van Overwalle and Leys have argued that patent law will accommodate 3D printing - much like it has other forms of emerging technologies. ${ }^{159}$ Taking a middle ground, Syzdek has suggested that there will be a pattern of gradual accommodation of $3 \mathrm{D}$ printing within the doctrines of patent law. ${ }^{160}$ Gibb - an open source hardware developer - has wondered about the death of patents altogether. ${ }^{161}$

153 Brief of Software Freedom Law Center, Free Software Foundation, and Open Source Initiative as Amici Curiae in Support of Respondents in Alice Corporation Pty Ltd v CLS Bank International 2014 WL 828022.

$154 \quad$ Bilski v Kappos 561 U.S. 593; Mayo Collaborative Services v Prometheus Laboratories 566 U.S. 66 (2012); Association for Molecular Pathology v Myriad Genetics Inc. 133 S. Ct 2107 (2013); and Alice Corporation v CLS Bank International 57 U.S. 208 (2014).

$155 \quad$ J Pearce, Open-Source Lab: How To Build Your Own Hardware and Reduce Research Costs (Elsevier, 2014), 53.

156 ibid, 54.

157 ibid, 55.

158 M Lemley, 'IP in a World Without Scarcity', (2015) 90 New York University Law Review 460-515.

159 G Van Overwalle and R Leys, '3D Printing and Patent Law: A Disruptive Technology Disrupting Patent Law?' (2017) 48 (5) International Review of Intellectual Property and Competition Law 504-537.

$160 \quad$ N Syzdek, 'Five Stages of Patent Grief to Achieve 3D Printing Acceptance' (2015) 49 University of San Francisco Law Review 335-360.

161 A Gibb, 'The Death of Patents and What Comes After', TEDxStockholm, 12 December 2012, $<$ https://www.youtube.com/watch? $\mathrm{v}=\mathrm{Z} \quad$ Sbw1Ax40 $>$ 
In this context, Fried, Adafruit, and the Open Source Hardware Association have been engaged in a range of policy debates about patent law, policy, and practice.

\section{A. Patent Law Reform}

There has been much controversy over software patents in the US. ${ }^{162}$ Adafruit was heartened by the decision of the US Supreme Court in Alice v CLS Bank. ${ }^{163}$ The comment noted: 'There will be debate about how far this ruling goes, but it does go $100 \%$ in the direction of abolishing software patents.' ${ }^{164}$ Adafruit was also pleased that the US Supreme Court sided with Newegg against an alleged patent troll in Soverain Software LLC v Newegg Inc. ${ }^{165}$

On a fireside hangout on Google+, Fried of Adafruit has personally called for patent law reform in an address to President Barack Obama. ${ }^{166}$ She discussed the problem of abuses in respect of software patents:

On the topic of legislation, I'm an entrepreneur and I think start ups are an important engine of the American economy. But when I go around and talk to other entrepreneurs what I hear is, they're worried that if they become successful, they're going to be targeted by software patent trolls. These are firms that collect software patents just for the purpose of litigation and getting money out of small companies that can't afford patent defence. They're expensive. ${ }^{167}$

Fried pressed the US President in terms of his policy response to the abuse of software patents: 'I'm wondering what are you planning to do to eliminate the abuses of software patents? ${ }^{168}$

162 W Seltzer, 'Software Patents and/or Software Development' (2013) 78 Brooklyn Law Review 929-987.

163 Adafruit, 'Breaking news - Alice v CLS Bank ruling by US Supreme Court on 19 June 2014', Blog, 19 June 2014, <https://blog.adafruit.com/2014/06/19/breaking-news-alice-v-cls-bank-ruling-by-us-supreme-courton-19-june-2014-patents/>

164 ibid

165 Adafruit, 'Supreme Court Sides with Newegg Against Patent Trolls', Blog, 14 January 2014, $<$ https://blog.adafruit.com/2014/01/14/supreme-court-sides-with-newegg-against-patent-trolls-makerbusiness/> 166 Adafruit, 'Ladyada on President Obama's Fireside G+ Hangout', YouTube, 15 February 2013, $<$ http://www.youtube.com/watch?v=Kw9fhI8pRMA $>$ See also Adafruit, 'Let's Help Fix the Patent System Together', <https://www.adafruit.com/patents $>$

$167 \quad$ ibid

$168 \quad$ ibid 
She also expressed concern about the duration of patent protection for software - relative to the commercial life of software: 'For example, would you be supportive of limiting software patents to only five years long? ${ }^{169}$

In response, Obama provided a defence of his record in respect of patent law reform:

\begin{abstract}
We actually passed some legislation that made progress on some of these issues, but it hasn't captured all the problems and the folks that you're talking about are a classic example. They don't actually produce anything themselves, they're just trying to essentially leverage and hijack somebody else's idea and see if they can extort some money out of them. And, sometimes these things are challenging because we also want to make sure that the patents are long enough that people's IP is protected. We've got to balance that with making sure that they're not so long that innovation is reduced. ${ }^{170}$
\end{abstract}

However, Obama conceded 'that our efforts at patent reform only went about halfway to where we need to go. ${ }^{171}$ He stressed that 'what we need to do is pull together additional stakeholders and see if we can build some additional consensus on some smarter patent laws. ${ }^{172}$ The Obama administration passed the America Invents Act, and took some action against patent trolls. ${ }^{173}$ Perhaps, though, it is an over-reaching claim to suggest that 'history will remember Obama as the great slayer of patent trolls' ${ }^{174}$ Obama maintained that he preferred a stakeholder consensus approach to dealing with IP reform. ${ }^{175} \mathrm{He}$ nonetheless recognised that there were some outstanding issues in the field: 'We have to keep on working on them.' ${ }^{176}$ Obama has since reflected upon his successes and failures in his tenure as President. ${ }^{177}$

As noted by Lemley, the patent system has been notoriously resistant to reform. ${ }^{178}$

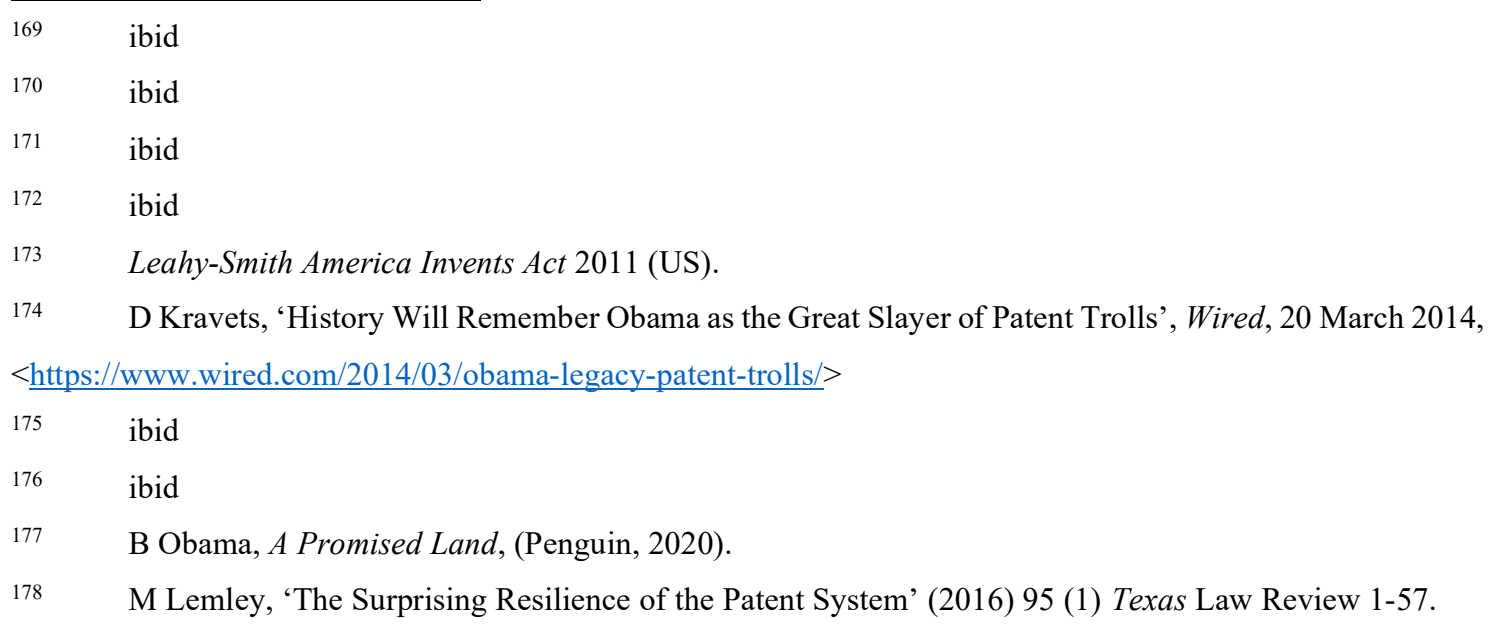




\section{B. Defensive Patenting}

There has been a growing interest in the use of patent pledges as a means of limiting the exploitation and enforcement of patents. ${ }^{179}$

In the meantime, Adafruit has decided to adopt defensive patents, observing: 'However it's hypocritical to talk about how patents should or should not be used unless you have some skin in the game, so we decided to get a patent and try to start a defensive patent pool for opensource hardware companies.' ${ }^{180}$ In particular, they were inspired by Andrew 'Bunnie' Huang's idea of 'Patent' $\mathrm{X}$ - or what was called the chumby HDK (Hardware developer kit). ${ }^{181}$ Huang said in an interview that 'the most important provision of the chumby HDK license is that in exchange for chumby sharing our technology with you, it requires you, under certain conditions, to share your technology with chumby.' ${ }^{182}$ Huang noted that this mechanism 'creates a pool of cross-licensed patents within the chumby ecosystem'. ${ }^{183}$ Huang observed: 'This pool is important because if a troll comes along and decides to threaten the ecosystem by asserting their patent rights to chumby or chumby-derivative products, then the entire pool of created patents are available to fight the troll., ${ }^{184}$

Adafruit was also inspired the coalition of technology companies, which sought to cross-license patents in order to ward off patent trolls. ${ }^{185}$

Adafruit has explained its approach to patents: 'Any patent we have present, past or future will always be available for any open-source hardware company to use free of charge'. ${ }^{186}$ The

$179 \quad$ J Contreras, 'Patent Pledges' (2015) 47 (3) Arizona State Law Journal 543-608; J Contreras and M Jacob (ed.), Patent Pledges: Global Perspectives on Patent Law's Private Ordering Frontier (Edward Elgar Publishing, 2017); and J Contreras, 'The Evolving Patent Pledge Landscape', (2018) CIGI Paper Series No. 166.

180 Adafruit, 'Let's Help Fix the Patent System Together', <https://www.adafruit.com/patents>

181 A Huang, The Hardware Hacker: Adventures in Making and Breaking Hardware (n 33).

182 Chumby One Hardware Docs, <https://www.bunniestudios.com/blog/?p=692>

183 ibid

184 ibid

185 L Gannes, 'Google, Canon, Dropbox and Others Pool Patents to Ward Off Trolls', Record, 9 July 2014, < $\underline{\text { https://www.vox.com/2014/7/9/11628688/google-canon-dropbox-and-others-pool-patents-to-ward-off-trolls }>}$ 186 Adafruit, 'Let's Help Fix the Patent System Together', < $<$ https://www.adafruit.com/patents $>$ 
company warns that 'if a patent troll comes after one of us, we may be able to pool our patents together to fight them off.' ${ }^{187}$ Adafruit subscribes to the Open Network License, which includes 'patent cross-licenses and releases from claims of patent infringement among its licensees.' 188 Adafruit comments that such a system 'encourages collaboration between Linux companies.' 189 Moreover, 'These patents could also be used to defend Linux vendors and developers from anti-Linux companies' legal attacks.' 190

Adafruit also notes that Twitter has also come up with the 'Innovator's Patent Agreement'. ${ }^{191}$ With approval, it notes that 'The IPA is a new way to do patent assignment that keeps control in the hands of engineers and designers'. ${ }^{192}$ Adafruit observes that 'it is a commitment from Twitter to our employees that patents can only be used for defensive purposes' and 'We will not use the patents from employees' inventions in offensive litigation without their permission'. ${ }^{193}$ There is certainly larger work being done in respect of patent pledges. ${ }^{194}$

Fried and Adafruit have obtained a patent in respect of one particular invention, 'Coordinated Wearable Lighting System'. ${ }^{195}$ The abstract says that the invention is 'a co-ordinated lighting system capable of affixation to a wearable garment is provided' ${ }^{196}$ The summary elaborates: 'According to more particular aspects of the invention, the system includes: a controller and a plurality of light emitting diodes (LEDs) arranged as a chain, at least one of the plurality of LEDs operatively connected to the controller.' ${ }^{197}$ Curiously, the work of Adafruit has often been cited as prior art in other patent applications.

$\begin{array}{ll}187 & \text { ibid } \\ 188 & \text { ibid } \\ 189 & \text { ibid } \\ 190 & \text { ibid } \\ 191 & \text { ibid } \\ 192 & \text { ibid } \\ 193 \quad \text { ibid } \\ 194 \quad \text { J Contreras, 'Patent Pledges' (n 179). } \\ 195 \quad \text { L Fried (inventor) and Adafruit Industries (Assignee), 'Coordinated Wearable Lighting System', US } \\ \text { Patent } \text { Registration No: US9226369B2, Priority Date: 12 November 2012, Filing Date: 12 November 2013, } \\ \text { Publication Date: 29 December 2015, <https://patents.google.com/patent/US9226369B2/> } \\ 196 \quad \text { ibid } \\ 197 \quad \text { ibid }\end{array}$


Adafruit said that the patent 'has not been used offensively or defensively and so far no one has asked to license it, so far it doesn't look like we're going to get it any way, but we tried.' 198 Adafruit observed: 'We'll continue to try to get at least one so we can have something to share/give away with other companies like ours'. ${ }^{199}$ Adafruit commented that there are other open-source hardware companies with patents. littleBits has, for instance, obtained a patent in respect of 'Modular electronic building systems with magnetic interconnections and methods of using the same'. ${ }^{200}$ The company has been building a small portfolio of patents. ${ }^{201}$ Chumby Industries Inc. also has been building a portfolio of patents. ${ }^{202}$

There has been a discussion about developing standardised terms and conditions for open patenting. ${ }^{203}$

\section{Patent Exhaustion}

The Open Source Hardware Association was part of an amicus brief submitted to the US Court of Appeals for the Federal Circuit in the dispute between Lexmark International Inc. $v$ Impression Products Inc. ${ }^{204}$ Other participants in the brief included Public Knowledge, the EFF, the Digital Right to Repair Coalition and Public Citizen. The matter involved Lexmark seeking to find a loophole in relation to patent exhaustion in relation to its $2 \mathrm{D}$ printers.

\footnotetext{
198 Adafruit, 'Let's Help Fix the Patent System Together', < $\underline{\text { https://www.adafruit.com/patents }>}$

199 ibid
}

200 A Bdeir (inventor) and littleBits Electronics Inc. 'Modular Electronic Building Systems with Magnetic Interconnections and Methods of Using the Same', US Patent Registration No. US9419378B2, Priority Date 26 $\begin{array}{llllll}\text { August 2011, } & \text { Publication } & \text { Date } & 16 & \text { August }\end{array}$ $<$ https://patents.google.com/patent/US9419378B2/en?assignee=littlebits $>$

201 littleBits, 'Patents', <https://littlebits.com/pages/patents>

202 Chumby Industries Inc., 'Patents', <https://patents.justia.com/assignee/chumby-industries-inc $>$

203 M Maggiolino and ML Montagnani, 'Standardized Terms and Conditions for Open Patenting' (2012) 14 Minnesota Journal of Law, Science and Technology 785-816.

204 Brief of Public Knowledge, the Electronic Frontier Foundation, the Open Source Hardware Association, the Digital Right to Repair Coalition, and Public Citizen Inc. as Amici Curiae in Support of Appellant Impression Products in Lexmark International Inc. $v$ Impression Products Inc., 19 June 2015, $<$ https://www.publicknowledge.org/assets/uploads/documents/brief-lexmark-v-impression.pdf> 
The submission explains: 'Open source hardware is hardware whose design is made publicly available so that anyone can study, modify, distribute, make, and sell the design or hardware based on that design'. 205

First, the submission argued that patent exhaustion is a consumer protection doctrine, which should be broadly construed to protect personal property ownership rights. The brief observed that 'copyright and anti-circumvention cases disapprove of using IP Law to control use of purchased goods. ${ }^{206}$ The submission argued that 'the law has long disfavored limits on free alienation of property to protect consumers. ${ }^{, 207}$ The brief maintained that 'patent exhaustion promotes numerous important consumer interests. ${ }^{208}$

Second, the submission maintained that the Jazz Photo decision should be overruled, ${ }^{209}$ as an International authorized sale should give rise to exhaustion. The submission insisted that international exhaustion is the preferable policy, because it avoids anti-competitive effects.

Third, the submission suggested that Post-Sale restrictions on use of a product do not abrogate patent exhaustion for that product. The submission maintained that the conditional sale doctrine permits manufacturers to burden consumers' use of purchased goods unduly. The submission suggested that the IP Law should not become a vehicle of contract enforcement against nonprivy third parties.

The majority of the US Court of Appeals for the Federal Circuit found in favour of Lexmark International. ${ }^{210}$ However, that ruling was overturned on appeal. In the end, the US Supreme Court held in 2017 that the patent holder cannot sue for patent infringement relating to the further use of a patented item, after sale. ${ }^{211}$ Roberts CJ reflected upon patent exhaustion: 'Allowing patent rights to stick remora-like to that item as it flows through the market would

\footnotetext{
$205 \quad$ ibid

$206 \quad$ ibid

$207 \quad$ ibid

$208 \quad$ ibid

209 Jazz Photo Corp. v International Trade Commission 264 F. 3d 1094 (Fed. Cir. 2001).

$210 \quad$ Lexmark International Inc. v Impression Products Inc., 816 F. 3d 721 (2016).

$211 \quad$ Impression Products, Inc. v Lexmark International Inc., 137 S. Ct. 1523 (2017).
} 
violate the principle against restraints on alienation'. ${ }^{212}$ Roberts CJ held that the patentee had exhausted its patent rights with respect to domestically sold cartridges. Roberts $\mathrm{CJ}$ also ruled that the patentee had exhausted its patent rights with respect to internationally sold cartridges. Ginsburg J provided a partial dissent from the court's holding with respect to imported items: 'A foreign sale, I would hold, does not exhaust a U.S. inventor's U.S. patent rights.' 213

Adafruit claimed that this decision was a 'victory for the right to tinker' ${ }^{214}$ Adafruit cited with approval a summary of the case by the EFF, which commented that 'the decision reinforces the freedoms of device owners and fends off the monopolistic threat of patent rights eliminating fair, essential competition in markets for repair and third-party innovation'. ${ }^{215}$ Adafruit has been supportive of efforts to recognise a right to repair in the US. ${ }^{216}$

\section{Conclusion}

This paper has sought to provide a portrait of Fried and Adafruit, and their contributions to Open Source Hardware. As Cory Doctorow has recently observed, open licensing practices have been challenged by the expansion of a range of fields of IP. ${ }^{217}$ In the field of copyright law, there remain tensions between proprietary approaches to information technology, and models of open licensing. The expansion of copyright protection in the wake of the US Supreme Court decision in Star Athletica v Varsity poses a particular challenge for the open source industry and the Maker Movement. Technological protection measures - digital locks - remain particularly problematic for the development of open source software and hardware. In the area of trademark law, Adafruit has highlighted the complexities of open source business.

\footnotetext{
$212 \quad$ ibid at 1538.

$213 \quad$ Impression Products, Inc. v Lexmark International Inc., 137 S. Ct. 1523 at 1538 (2017).

214 Adafruit, 'Supreme Court Victory for the Right to Tinker in Printer Cartridge Case', Blog, 30 May 2017,

$<$ https://blog.adafruit.com/2017/05/30/supreme-court-victory-for-the-right-to-tinker-in-printer-cartridge-case$\underline{\text { eff-lexmark/> }}$

215 K Walsh, 'Supreme Court Victory for the Right to Tinker in Printer Cartridge Case', EFF, 30 May 2017 , <https://www.eff.org/deeplinks/2017/05/supreme-court-victory-right-tinker-printer-cartridge-case>

216 Adafruit, 'Fix, or Toss? The "Right to Repair” Movement Gains Ground', Blog, 3 November 2020, <https://blog.adafruit.com/2020/11/03/fix-or-toss-the-right-to-repair-movement-gains-ground/>

217

C Doctorow, 'IP', Locus Magazine, September 2020, <https://locusmag.com/2020/09/cory-doctorowip/>
} 
Adafruit has been involved in a skirmish of trade mark rights - which apparently settled later. The Open Source Hardware Association has been concerned about developments in respect of design patents. The Association has called for a balanced approach to the protection of design patents. Limor Fried and Adafruit have called patent law reform - particularly in respect of software and hardware patents. In the meantime, the company has sought to engage in defensive patenting as part of a networked effort to ward off patent trolls. The Open Source Hardware Association has also intervened as an amicus curiae in patent disputes over 2D printing. Limor Fried and Adafruit have demonstrated the important role of the Open Source Hardware movement in lobbying for IP law reform.

In addition to advocating for Open Source solutions and IP law reform, Limor Fried has also advocated for better inclusion and diversity in STEM disciplines. Adafruit has highlighted the struggle for gender parity in the arena of IP. ${ }^{218}$ In the Google+ fireside chat, Fried asked Obama: 'Have your daughters expressed any interest in pursuing a career in science or engineering?' ${ }^{219}$ In response, Obama observed that 'we need to have more girls interested in math, science, and engineering'. ${ }^{220}$ As Kelsey Merkley has observed, the open movement needs to be more than just a set of technical open licensing contracts and standards. ${ }^{221}$ There is a need to ensure that the open movement recognises gender equality and cultural diversity. The free software, open source software, and Creative Commons communities need to be more inclusive - so that they practise what they preach. ${ }^{22}$ The United Nations Sustainable Development Goals have highlighted the importance of gender equality - including in innovation. ${ }^{223}$ Recent statistics

218 Adafruit, 'The Struggle for Gender Parity in the Arena of Intellectual Property Continues But We Are Improving', Blog, 27 April 2018, <https://blog.adafruit.com/2018/04/27/the-struggle-for-gender-parity-in-thearena-of-intellectual-property-continues-but-we-are-improving-worldipday/>

219 Adafruit, 'Ladyada on President Obama's Fireside G+ Hangout', YouTube, 15 February 2013, $<$ http://www.youtube.com/watch?v=Kw9fhI8pRMA $>$

$220 \quad$ ibid

221 K Merkley, 'Horizontal Hostility', the Creative Commons Summit 2019, 10 May 2019, $<\underline{\text { https://youtu.be/1Y0FuH5FNCo }}>$

222 A Burek et al. 'Feminist Hackerspaces', in J Sayers (ed.), Making Things and Drawing Boundaries: Experiments in the Digital Humanities (The University of Minnesota Press 2017), 221-231; and J Maher, 'Women's Hacking of the Poison Gift of Free/ Libre/ Open Source Software', in J Hunsinger and A Schrock (ed.) Making Our World: The Hacker and Maker Movements in Context (Peter Lang Publishing, 2019), 171-196.

223 United Nations Dustainable Gevelopment
$<$ https://www.un.org/sustainabledevelopment/sustainable-development-goals/> 
from WIPO have revealed that the gender gap has been persistent in IP - with just one in 6 inventors in patent applications being a woman. ${ }^{224}$

In addition to dealing with questions of IP and innovation policy, Adafruit has also had to weather the public health crisis of the coronavirus, and the ensuing economic recession. During the COVID-19 outbreak, Adafruit is operating as an essential service and manufacturing business under - NYC - Executive Order 202.6 making PPE and medical device components. Adafruit became involved in crisis relief in 2020 after New York City officials put a call out for the local manufacturing businesses to address shortages in personal protective equipment and medical devices. ${ }^{225}$ Adafruit managing director Phillip Torrone commented: 'Because we do production, laser cutting, all sorts of things that you need to do, we said 'Sure, sign us up.'226 Adafruit has been deemed an 'essential service', meaning that it can continue to operate during a shutdown. ${ }^{227}$ Adafruit has also played a role in preparing for a COVID-19 recovery in the US. Limor Fried has been appointed to the Small Business Sector Advisory Council by the City of New York to help restart the NYC economy post COVID-19 pandemic. ${ }^{228}$ The public health crisis has certainly highlighted the role of the Maker Movement and open source hardware in local manufacturing. ${ }^{229}$

In the future, it would be worthwhile exploring the distinctive open source hardware culture in the EU, and its neighbours such as Switzerland. From its base in Switzerland, CERN has played

224 WIPO, 'WIPO Publishes New Statistics on Female Inventors in PCT International Patent Applications', 24 May 2019, <https://www.wipo.int/women-and-ip/en/news/2019/news 0002.html>

225 R Chan, 'Electronics Manufacturing Company Adafruit has seen a 90\% Plunge in Sales During the Coronavirus Pandemic, But It's Been Able to Overhaul its Operations to Build Medical Supplies for Crisis Relief', Business Insider, 26 April 2020, <https://www.businessinsider.com.au/adafruit-builds-ppe-medical-devicescoronavirus-crisis-2020-4? $\mathrm{r}=\mathrm{US} \& \mathrm{IR}=\mathrm{T}>$

226 ibid

$227 \quad$ ibid

228 The City of New York, 'Mayor de Blasio Appoints Members to Sector Advisory Councils', Press Release, 6 May 2020, <https:/www1.nyc.gov/office-of-the-mayor/news/326-20/mayor-de-blasio-appoints$\underline{\text { members-sector-advisory-councils }>}$

$229 \quad$ M Ehrhardt, 'Electronics Maker Adafruit Switches to Producing Face Shields, Other PPE', Tom's Hardware, 13 April 2020, <https://www.tomshardware.com/news/adafruit-making-ppe> 
a key role in the development of open source hardware licensing. ${ }^{230}$ Such a system has been built out of a model of collaborative and collective scientific authorship. ${ }^{231}$ Moreover, CERN has been a champion of open science. ${ }^{232}$ There are also a number of distinctive maker companies in the EU - such as the 3D printing company Prusa Research in the Czech Republic - which would be worthwhile profiling. There is also a prominent culture of networked Fab Labs and hackerspaces in the EU - which have subscribed to open models of licensing, including free software, open software, and open hardware licensing. ${ }^{233}$

There is also a larger need to globalise the open source hardware movement. Much like the Creative Commons movement has evolved from a North American entity to a global network of Creative Commons chapter, the open source hardware movement does need to go beyond its bases in the US, the EU, and Switzerland, and develop into a truly international campaign. As the Open Source Hardware Weather Report 2020 indicates, the movement is still relatively young at 10 years of age, and does have potential for future evolution and growth. ${ }^{234}$

\footnotetext{
230 D Antonio, 'CERN Updates Its Open Hardware Licence', CERN, 12 March 2020, $<$ https://home.cern/news/news/knowledge-sharing/cern-updates-its-open-hardware-licence>

231 D Simone, Copyright and Collective Authorship: Locating the Authors of Collaborative Work (CUP 2019), 136-137, 145-148.

232 M Bachelet, 'A Joint Appeal for Open Science by CERN, OHCHR, UNESCO and WHO', Press Release, United Nations Human Rights: Office of the High Commissioner, 27 October 2020,

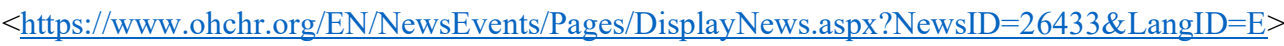

233 M Menichinelli (ed.) Fab Lab: Revolution Field Manual (n 76).

234 C Redwine and M Weinberg, Open Source Hardware Weather Report 2020 (Engelberg Center on Innovation Law and 2020), $<$ https://www.law.nyu.edu/sites/default/files/2020_OSHW Weather_Report.pdf>
} 